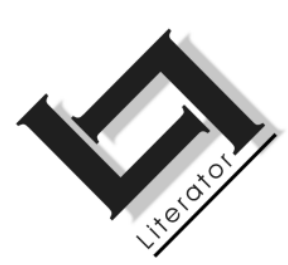

\title{
One rainbow, one nation, one tongue singing: whiteness in post-apartheid pulp fiction
}

\author{
M.E. West
}

Department of Language \& Literature

Nelson Mandela Metropolitan University

PORT ELIZABETH

E-mail: Mary.West@nmmu.ac.za

\begin{abstract}
One rainbow, one nation, one tongue singing: whiteness in post-apartheid pulp fiction
\end{abstract}

A certain brand of fiction has become popular in post-apartheid South Africa that accounts for the relative success of Susan Mann's "One tongue singing" (2005). This article seeks to examine the implications of narratives such as this in revealing the normative assumptions that might inform text and reception a decade into a new democracy. It begins with an overview of whiteness studies as a post-colonial frame of reference useful in gauging the continued hegemonic normativity of whiteness as a cultural affiliation. This is followed by an analysis of Mann's novel. I argue that it is precisely in fiction such as this - massproduced for a white middle-class, mostly female readership both here and abroad - that there is ample evidence of the kinds of normative assumptions that whiteness studies attempts to make visible. I demonstrate that despite the writer's liberal and politically correct attempts to negotiate the politics of race, gender and class, her narrative inadvertently reinforces stereotypes that it ostensibly challenges. Thus it exhibits the discursive limits and powers of the most readily available reading matter this country has to offer. 


\title{
Opsomming
}

\section{Een reënboog, een nasie, een singende tong: witheid in postapartheid pulpfiksie}

\begin{abstract}
Susan Mann se "One tongue singing" (2005) het sy relatiewe sukses te danke aan 'n bepaalde soort fiksie wat gewild geword het in Suid-Afrika na apartheid. Hierdie artikel is 'n poging om die implikasies van narratiewe van hierdie aard te ondersoek, veral om die normatiewe opvattings te ontbloot wat die grondslag vorm van hierdie tipe tekste en hulle ontvangs 'n dekade sedert die nuwe demokrasie tot stand gekom het. Eerstens gee ek 'n oorsig van witheid ('whiteness') as studieveld wat dien as 'n postkoloniale verwysingsraamwerk vir die beoordeling van die volgehoue hegemoniese normatiwiteit van witheid as 'n kulturele verwantskap. Daarop volg 'n analise van Mann se roman. Ek voer aan dat daar juis in hierdie soort fiksie - wat op groot skaal vir die plaaslike sowel as oorsese wit middelklas, en veral vir 'n vroulike leserspubliek geproduseer word - genoegsame bewys is van die normatiewe opvattings wat witheidstudies probeer blootlê. Ek toon aan dat, ten spyte van die skrywer se liberale en polities korrekte pogings om die politiek van ras, geslag en klas te beheers, die narratief onbedoeld daardie stereotipes versterk wat dit oënskynlik probeer uitdaag. Daardeur illustreer dit juis die diskursiewe beperkings en vermoë van geredelik verkrygbare leesstof in die land.
\end{abstract}

\section{Introduction}

In reading a representative selection of literary texts produced in contemporary South Africa by white women writers, my broader project (cf. West, 2009) examines the ways in which so-called liberal writing by white women - promoted by international and highly reputable publishing houses - is uncomfortably both consciously in support of, and unconsciously at odds with, emergent reconciliatory gestures and multicultural celebrations of "rainbow" nationhood. An examination such as this enables an assessment of the extent to which white identities continue to be characterised by a largely unconscious (and thus unexamined) set of assumptions, and a concomitant sense of entitlement that manages to hold currency, despite more than fifteen years of democracy. These assumptions are not easy to identify, and in fact often do not seem to be assumptions at all. Indeed, the very notion of normativity, resists being read as a sense of entitlement precisely, because such responses do not manifest themselves, without paying particular attention to them, other than normative. Contemporary writing emerging in South Africa is 
marked by a preoccupation with "race". White writing in particular, is characterised by an uneasy ambivalence, which becomes apparent when one examines the interstitial manifestations of residual liberalhumanist assumptions that are at odds with conciliatory gestures. This renders a revealing duplicity that the writers under scrutiny in my larger study, either acknowledge and investigate, or ignore and perpetuate - even at times manifesting both responses simultaneously.

This article attempts to demonstrate this phenomenon and the residual effect of particular discursive formations - integrally related to gender and class - that favour whiteness as a racial category, despite official policies that have shifted the racial marker into a less than comfortable position. I focus on a single representative text, One tongue singing (2005) by Susan Mann, to gauge what sustains such responses. Perhaps the most significant element of these discursive formations is Western liberal humanism itself, a discourse that has often been instrumental in maintaining the narrow-mindedness and assumptions that have emerged as normative. 1 The liberal humanist in the history of South Africa's political turmoil has often been the white English-speaking product of a privileged and educated background. Such an individual, who has been allowed the comfort of disapproving of, even resisting, the apartheid regime and racism generally, but from a position of relative safety, as a result of material privilege and empowerment through knowledge, and the universality of Englishness. To assess the continued effect of such discourses and to examine the extent to which whiteness as a cultural construct continues to exert its influence on race relations in post-apartheid South Africa, I offer a reading of one contemporary work of popular, mass-produced pulp fiction and explore its negotiation of race and belonging. By (re-)reading a text produced by a white woman writer in the light of contemporary theories that have collectively been labelled whiteness studies, I demonstrate that racial hierarchies in post-apartheid South Africa have in many ways not been renegotiated and that white normativity remains largely unexamined. I suggest that this kind of literature is marked by an uneasy duality, a duality that hinges on the continued effects of whiteness, as an "unmarked marker"2 in a Western liberal humanist

1 Robert Young (2004) plots the history of white Western liberal humanism and demonstrates its complicity in colonialism.

2 The concept is widely used in whiteness studies, but associated most readily with the pioneering work of Ruth Frankenberg (1993). Other scholars have 
tradition, which continues residually to mark race representations and race relations in post-apartheid South Africa.

\section{Whiteness}

The field of whiteness studies offers a broad post-colonial set of theoretical ideas that may be employed to examine the largely invisible ways in which white identity continues to suggest what is normal and universal, even as white Western-hood is either challenged from contesting literatures and criticism, or repudiated from within its own self-regulating discourse. Bhabha, in his "White Stuff" essay (1998), suggests that interrogating whiteness is necessary but difficult. He expresses his reservations in relation to Noel Ignatiev's (2005) call for the abolition of whiteness. He suggests that such abolition may never be accomplished, because, as an identification, whiteness is an elusive quality that might simply continue "its 'nationalist' agenda under the guise of 'civility', 'secularism', 'tolerance', or even 'national culture'" (Bhabha, 1998:24). A similar danger in pursuing whiteness studies is articulated by Samina Najmi and Rajini Srikanth (2002:3), who argue that the trend carries with it the possibility of "eclips[ing] the universal power of whiteness"3 and obscuring the seemingly trivial but multiple ways in which liberal white people continue to benefit socially and economically in direct proportion to that universal power. As Bhabha (1998:21) has pointed out (following Foucault), "the place of power is always somehow invisible, a tyranny of the transparent". The most engaged and selfconscious of the writers that have been examined, make visible such a tyranny and demonstrate an awareness of the fact that "in the present state of political and social fluidity, the signifiers are at play" (Steyn, 2001:151). Bhabha (1998:21) points out that

employed the Lacanian terms empty signifier (cf. Wicomb, 2001:169), or master signifier (Seshadri-Crooks, 2000:58) which are interchangeable with the notion of an "unmarked marker".

3 They (Najmi \& Srikanth, 2002:3) note that the universalising aspect of this kind of power

persists across its particular manifestations, cuts through specificities, and devastates those who fall within its purview. Thus, to say that whiteness is not monolithic and to demonstrate that it is a nuanced construction reflects a disingenuous refusal to acknowledge the destructive effects of white power, which, in its overwhelming effect on the lives of people, carries the weight of the universal. Many contemporary whites steeped in Civil Rights ideologies, disaffiliate from segregationist and white supremacist practices to declare themselves anti-racist. 
... 'whiteness' naturalizes the claim to social power and epistemological privilege, [and therefore] displacing its position cannot be achieved by raising the 'gaze of the other' or by provoking the 'return' of the repressed or the oppressed. The subversive move is to reveal within the very integuments of 'whiteness' the agonistic elements that make it the unsettled, disturbed form of authority it is - the incommensurable 'differences' that it must surmount; the histories of trauma and terror that it must perpetrate and from which it must protect itself, the amnesia it imposes on itself; the violence it inflicts in the process of becoming a transparent and transcendent force of authority.

Despite more than fifteen years of democracy, and despite official efforts to rethink racial politics, whiteness in South Africa continues to exude a sense of normativity and exhibits the amnesia that Bhabha identifies. This has recently been overlaid with defensiveness, an ambivalent and dangerous combination that resists, rather than assists, the process of reconciliation, and deepens racial divisions. Whiteness operates as a cultural force, which to some extent relieves white people of having to negotiate their whiteness, except as defensiveness. The fixity of whiteness as a racial identification is best understood in terms of reification and valorisation. Both concepts emerged out of Marxist critiques of power relations, and denote the invisible ways in which ideology operates to essentialise and naturalise constructed differences. This reifying tendency may best be understood as the hegemonic privileging of the white Western self. Raka Shome (1999:108)4 defines whiteness as a "powerladen discursive formation that privileges, secures, and normalises the cultural space of the white Western subject" and notes in particular the reproductivity inherent in the neo-colonial and figurative "travelling" of white cultural products, including academic texts. Shome's inclusion of academic texts in her catalogue of transferable cultural products makes it necessary to take cognisance of the reproductivity of white normalcy in textual production and reception, or how certain ideas flourish as a result of the publishing industry and

$4 \quad$ Shome (1999:108) explicitly lists these products and suggests that in addition to the historical and

physical travel of white imperial bodies colonizing 'other worlds' (...) today's neo-colonial travel of white cultural products - media, music, television, products, academic texts, and Anglo fashions - to 'other worlds' [has] (...) sustained [the] forces of imperialism and global capitalism. 
the readers who subscribe to it, though the latter formulation might well also work in reverse.

\section{Disgrace-lite}

Susan Mann's One tongue singing (2005) offers a productive site to interrogate the enactment of whiteness. It constitutes a prime example of a promoted genre emerging in South Africa, identified by Robert Kirby (2005:23) as "post-apartheid weepies" written by "guiltridden white women" who have found a niche market in appealing to a premature celebration of new South African rainbow nationhood, without having to negotiate the real politics of white normativity. I introduce this novel to consider how it challenges the mores of white Western womanhood, or whether it merely reproduces and affirms the most normative and socially sanctioned values of most white readers. Fiction such as One tongue singing is published by reputable international publishers and is therefore readily available and well marketed. This kind of fiction is mass produced for a white middle class, mostly female readership both here and abroad. Though some might not agree with the identifying of this novel as pulp fiction, and call for a fully theorised justification for doing so, it is this author's intention to provoke a critical response to the publishing industry, what it promotes, and in the service of whose interests. The category is seen as simply a way of signalling the most popular and the most readily available reading material produced to satisfy target markets, like detective novels, sentimental romance fiction, or Wild West stories. Thus rather than justifying the choice, the following questions are posed as a way to contemplate the (in-)accuracy of identifying this novel as an example of pulp fiction. What might white South African women or the general public learn from books like these? How have South African realities been depicted? And how, if at all, have texts such as these negotiated the complex politics of gender, race and belonging in post-apartheid South Africa? In considering these questions in relation to this novel, the author of this article hopes to explore the complicities, clichés, and ghostliness of whiteness as a master signifier, which operates silently but effectively in the interstices of liberal Western discourses. This requires an investigation into the discursive repertoires upholding white normativity.

The book, first published by Secker and Warburg in 2004 and subsequently by Vintage in 2005, has been dubbed Disgrace-lite, and reviewers have commented on the similarities of character and plot in Disgrace and One tongue singing: both contain an ageing male 
artist/academic who gropes young female students, and both negotiate the violent sexual assault of a single white woman living in rural South Africa (Rosenthal, 2004:5; De Vries, 2004a:28; Swerdlow, 2003). The most important observation to be made in this regard is the derivative and socially-scripted inevitability of white preoccupations. The story is filled with the stereotypes that are the necessary ingredients of plot-driven, best-selling narratives, and thus particularly revealing in the politics of identity it explores. One tongue singing might well offer the reader of women's fiction a vision of the violence that is often an underlying precept of the sexual romance in a heterosexual economy of being. It may also, as Rosenthal (2004:5) has noted, despite "the lurching between penny novelette and passages of clearly didactic purpose, [prove] to be worth reading this novel through to the end". Nonetheless, the book relies on cliché even as it expressly opposes apartheid and its legacies, and thus inadvertently allows whiteness to emerge as normative, as the following analysis of Mann's contribution to post-apartheid literature will demonstrate.

André Brink (2004:18) describes Mann's contribution to postapartheid South African literature as "story-telling at its best", as "superb", and as "deceptively low-key but brilliant". The front cover quotation from Brink claims that it is "[s]ensitive and sharp and charged with authentic passion (...) a book that sings in a tongue of liquid fire". This is fiery praise from Mann's tutor in the creative writing course she completed at the University of Cape Town. The Guardian review printed on the back cover of the book provides another interesting response to the book, which takes cognisance of all its preoccupations - race, and class and gender:

Strong on characterisation, One Tongue Singing is an incisive and emotive reminder that power in human relationships always manages to transcend colour, gender, wealth or class. (Mann, 2005: back cover. $)^{5}$

This proves to be an even more fascinating summation of the novel than Brink's fiery praise, because the novel appears to demonstrate the exact opposite, namely that "power in human relationships" never "manages to transcend colour, gender, wealth or class", as the following exploration will endeavour to show.

$5 \quad$ References with only a page number refer to Mann (2005). 


\section{Forked tongues}

The single most far-reaching and climactic event narrated in the novel, is the rape and murder of a middle-class white woman by a man whose identity, though deliberately left undisclosed, is almost certainly a coloured 6 labourer, based on the narrative hints and cues the texts delivers. Among these are a multitude of stereotypes relating to gender, race, class and language that need to be catalogued. Camille Pascal, a nurse and unwed mother, leaves her homeland, France, with her father and her daughter to settle in South Africa, after the love affair with the child's father ends abruptly. The three foreigners settle in the parochial Stellenbosch wine-farming district during the height of apartheid. Here they lead a quiet life, keeping largely to themselves, though uneasily aware of the exploited and oppressed coloured community of farm labourers and the new settlement of shack-dwelling black people who occupy the territories adjacent to the farm. The first part of the scene is thus set for the judgemental juxtapositions of cosmopolitan French whiteness and parochial South African whiteness, of European liberal largesse, and settler conservatism. The elevation of a liberal European civility may be read in relation to what Levinas (1969:21) has termed ontological imperialism to plot Western philosophy and its tendency to neutralise and encompass difference in "its long history of desire for Unity and the One". This underscores the egotism characteristic of Eurocentrism. Such elevation of European whiteness is evident in other aspects of Mann's characterisation. For example, the lack of medical facilities prompts Camille to set up a practice, with the help of an Italian doctor (predictably not a South African), which she runs from home, dispensing medication, "[j]ust the basics: contraceptives, painkillers, antiseptics and some antibiotics" (p. 135), to the underprivileged other races during the height of apartheid. The second part of the scene is thus set for the inevitable: a vulnerable white woman at the mercy of rapacious drunken coloured men and/or even darker more threatening black men.

Four possible suspects for the murder of Camille Pascal emerge as the narrative unfolds. The list of suspects deliberately points to the uncertainty of the rapist-murderer's identity. The first is a drunk coloured man, "in torn overalls" whom Camille finds attempting to sexually harass her daughter, Zara (p. 150-151) and whom she threat-

6 The term coloured is still in use in South Africa to designate an apartheid legislated group of mixed-race decent. 
ens with a rock. The second is the white wine farmer, Mr Hermann Smit, who sold the land to the Pascals, and who offers her a lift home after a meeting of the Wynboerevereniging, 7 which Camille attends to convince the wine farmers to assist her financially with the clinic she intends establishing. As they walk towards the car, Mr Smit makes a pass at her (a fumbling hand touching her breast) to which she responds "spin[ning] like a whip, the thwack of her hand cutting through the night" (p. 157). The third is one of two black men who arrive at the clinic asking for work and food. When Camille disappears into the kitchen to make them sandwiches, one of them enters the house, but she is saved by the sound of a car arriving: "The tall man looks towards the source of the sound, before taking his sandwich and walking out." (p. 167.) The fourth and final suspect is the sangoma who treated one of Camille's black patients and who may have been angry that Camille had intervened and prescribed Western treatment (p. 226). It is Camille's father who provides the most revealing response to the list of suspects when he is questioned by the police, and coerced into blaming the "savage bunch" of "natives" (p. 226):

You know, Inspector, I have not lived here that long. But this much I do know: in this country it could have been anybody. Nobody of any colour, shape or creed seems to escape the dry brain rot here. A psychopath would be quite comfortable in any environment you choose. Yes, it could have been one of the labourers, blind drunk and violent after a night's drinking. Or one of the black people, erupting out of a mire of repression. Or the witch doctor, angry with her for interfering with his power. Or one of you! It could have been one of you, the white people of this place. After all, nobody seems to sin quite as expertly as you Calvinists. Pah!

Although the old man is right to identify an overt and overwhelming pathology inherent in South African race relations, and to include in his conjecture the sweep of pathologies engendered by exploitation and repression, one cannot help registering the possibility that in the tenor and trajectory of his response to the police inquiry, his inclusion of the white man is merely insulting rather than accusatory. In effect, the list, as verbalised by Mr Pascal, moves from most to least likely, or from real to rhetorical, as the following textual facts concerning the suspect reveals. Firstly, the reader is made more aware of alcohol abuse and the ensuing violence among the co- 
loured labourers, than of any other pathology related to race. The alcohol-induced violence prompts Camille to make enquiries about the dopstelsel (drink policy), 8 which "keeps [the workers] quiet, 'dronk', and dependent" (p. 82, 94). It is also a drunken coloured man who is asking Zara to show him her broekies (underwear) when Camille arrives to rescue her daughter from sexual abuse.

The only clue the reader is given about the identity of the rapistmurderer is that there is a "funny smell. Sour (...)" (p. 224), in the room when Zara enters and witnesses the killing of her mother. It is as likely as any other explanation that the sour smell is cheap wine, as registered from the point of view of a child. Cumulatively, these narrative clues are impossible to dismiss, rendering the novel's purpose (which Mann or her publisher on her behalf endorses, having afforded it book cover status) to demonstrate that "power in human relations always manages to transcend colour" effectively unaccomplished. This is promoted through the abiding stereotype of the coloured man in South Africa - he is a cowardly and incomplete man, unable to stand up to the oppressor, drunken and abusive, always caught with his pants down (p. 76, 224), prone to bouts of alcoholinduced violence, wife-battering, child-molestation, and, therefore, by implication, rape and murder. Such stereotyping reminds one of Frankenberg's (1993:290) "discursive repertoires", available to white middle-class women - repertoires that carry traces of colonial attitudes that continue to inform a so-called liberal response to new social realities. This aspect of the story thus belies the blurb's assessment of what the novel has achieved, because though the perpetrator of the heinous crime "could have been anybody" (p. 226), given the amount of stereotypical detail in evidence, it is more likely to have been a coloured man than any other character-type depicted. Thus the novel firmly entrenches rather than challenges the race, class and gender dynamics governing relations of power in South Africa. It may be argued that this depiction of the scenario is meant to reflect the political and social realities of the apartheid era, given that the incident takes place in an earlier temporality than the current narrative, which plots the development of Camille's daughter. Such a reading, however, would have to negotiate subsequent scenarios and the attendant characterisations, which do not convince the reader that power in South African relationships manage to transcend race, gender, class, wealth, or even culture.

8 The dispensing of cheap wine to the labourers at night and over weekends to supplement their meagre wages. 


\section{One tongue: Afrikaans}

Susan Mann might be said to have struggled to negotiate the dynamics of interracial politics in South Africa in her reliance on cliché to carry her condemnation of the rape and murder of Camille. What is arguably just as problematic is the writer's general disapproval of white South Africans, but white Afrikaans-speaking South Africans in particular. With the exception of the young Pieter, who defies his conservative boere parents by maintaining his friendship with Blom and Zara despite multiple beatings, there is not an Afrikaner in the story who is sympathetically portrayed. Jane Rosenthal's (2004:5) review rightly targets this aspect of the novel. "Afrikaner bashing," she writes, "is such a tired old cow, dragged once again from the sloot [ditch]". Afrikaners are depicted as boorish, ill-educated, inarticulate and unaccommodating of difference. Firstly, there is Mrs Smit with her "clipped colonial accent", "her white blouse stiffly starched" and her "gold-rimmed bifocals", p. 79), whose advice to Camille is to stay away from the coloureds, because they are "a violent lot" who "drink too much" (p. 80). Then there is Mrs Smit's husband, his "skin flushed, his small eyes darting to and from her body and face" (p. 81) who gropes Camille's breast. Next is Zara's teacher at Valley Land Junior Primary "with the beetle-shaped body and a nose for delinquency" (p. 48). Mrs Meijer with her "baguette-shaped arms" and "vein-spattered nose" (p. 50) is the consummate boeretannie (aunt), ${ }^{9}$ whose Calvinist wrath ensures that Zara's experience of the white public school system in South Africa is short-lived. And finally, there are the boers themselves who congregate once a month to discuss community affairs, and who are described as "large-boned men" with "powerful frames" and "strong jaws" made for Afrikaans, a "masculine" language "[h]andcrafted for the people by the people" (p. 155). This catalogue of quotations characterises the representation of the Afrikaans community in the novel. In each case, the Afrikaner remains irredeemably stereotyped, with the presence of each character serving merely as a backdrop to suggest white racist mentality and a colonial backwardness, which throws into relief the French gentility of the Pascals. Valerie Babb's (p. 33) plotting of a hierarchy in an American historical development of cultural/racial politics in which "English is the preferred form of white", may be extended to suggest that such an elevation of European civility marks another kind of preferred form of white. In this regard, one cannot overlook the implication that the author considers European white- 
ness as untainted and normative, and that it is Afrikaans-speaking white South Africans who must bear the full responsibility for apartheid, whilst their English-speaking counterparts remain relatively exempt.

\section{One tongue: English}

English-speaking white characters in One tongue singing are, however, not entirely exempt from the stereotyping evident in the unsympathetic representation of Afrikanerdom, though the two main characters, Jake Coleman and his wife Maria, in the narrative that alternates with the Camille Pascal story, are fleshed out to allow them some real substance. The narrative that features Jake and Maria is set between ten and fifteen years after the Camille Pascal murder story and commences with the arrival of Zara Pascal at the Jake Coleman International School of Fine Art. The old South Africa has been eradicated in this temporality, at least officially, and the new one is struggling to be born, but as the text amply demonstrates, not much has changed to challenge white English-speaking South Africans out of their insularity and liberal self-congratulating self-absorption.

Jake is cheating on his wife, a phenomenon that appears to be a characteristic feature in emerging fiction by white women, as Fred de Vries (2004b:9) has pointed out in his suggestion that in many of the novels he encountered in preparation for his article "Singular white females," the white "South African man is portrayed unflatteringly [as] macho, adulterous, materialistic and emotionally immature"). On one level, such depictions may be accommodated in responding to a history of Western literary representations of gender norms, which posit woman as overtly sexual, superficial and emotionally unstable, and man as the mature, responsible, rational proprietor of wily femininity. On another level, however, they do nothing to alleviate the anxiousness around masculinity that is inevitably heightened as a result of a too easy reliance on the abiding stereotype of masculine sexual excess. Though Jake is the villain of the story, it is clearly intentionally ironic that it is he and the dirty, scavenging art critic, Frank Rosen (also Jewish and the reader can draw her/his own conclusions), who offer the most acerbic take on white South African society. Jake comments on the bourgeois notion of romantic and monogamous love, labelling it a "rather irritating, middle-class, female preoccupation" and the "meagre product of a supreme lack of imagination". 
The demise of a mind small enough to be hemmed in by garden fences, corporate success stories and fifteen days' leave per annum (...). And in this country, the scenario would usually come complete with razor-wire trimmings and two corpulent, gas-filled Staffordshire bull terriers. (p. 6.)

Apart from the cleverly, and accurately, constructed image of white suburban South Africa - which is powerfully indicting - the irony here includes the fact that it is Jake who will fall romantically and dangerously in love (with his student, Zara), and it is himself who is thus guilty of perpetuating the "rather irritating, middle-class, female preoccupation" he condemns. Likewise, it is the disreputable Frank Rosen, with his "nicotine stained teeth" (p. 184) who, in addressing his cat, comments that "the nouveaux riches have inherited the earth. And art - or no, wait, creativity - is replacing tennis parties as the favoured hobby of this little troop of bored bourgeois plutocrats." (p. 185.) Perhaps Brink is right to suggest that Mann has purposefully and ironically given the "truest words" to the most unlikeable characters in order to demonstrate that "nothing can simply be taken at face value, that everything is loaded with multiple meanings and possibilities and alternatives" (Brink, 2004:18), but it is equally probable that any real critique of social mores is effectively neutralised emanating as it does from such unconvincing sources.

\section{White men}

Masculinity in the novel is an interesting site to examine the "tyranny of the transparent" and it is productive to note the depiction in the book of white masculinity, as opposed to black masculinity. The portrayal of white South African men is generally uncomplimentary, whereas the Frenchman Pappi Pascal, the Hungarian potter, Mátyás, and the Italian doctor, Belotti (who assists Camille in establishing a clinic), are admired for their cosmopolitan civility. This is problematic because for as long white South African male bashing remains popular, and elevating the gentility of European-white masculinity, one runs the risk of reifying white masculinity by default. Clearly, the beachcombing Italian doctor, Belotti, in addition to being the requisite "tall, dark handsome stranger" of romantic fiction, with his "sleek silver 1972 Mercedes sports car" (p. 137), and his ability to exhibit "grave concern one moment, and undiluted flirtation the next" (p. 135), also epitomises Western normativity. It is Dr Luca Belotti who has to undo the work of African traditional sangoma superstition (p. 169) by amputating the leg of a woman who had "stupidly", the narrative suggests, relied on traditional healing rather than on Western medicine. And though it is not within the scope of my expertise 
to assess the relative efficacy of either African or Western healing practices, this particular sub-plot lays the foundation for an uncomfortable binary that the narrative allows, even condones. Indeed, the black woman's response when Camille tells her that her foot will have to be "cut off" is shot through with overt zoological stereotyping of black subjectivities, from a white "weepie" perspective:

'Hawu!' She says. 'Oh my God'. She rolls her eyes, the whites veined and creamy. The other two women shake their scarved heads like chorus members in a Greek tragedy, making clicking sounds of disapproval. (p. 169.)

Mátyás, Zara's father, who operates on the fringes of the art-collecting in-crowd of Capetonian high society, is a foil against which Jake Coleman's artistic failure and sexual excess is amplified. Though both men have been adulterous, Mátyás's life is rendered as tragic (p. 234), whereas Jake Coleman is the butt-end of a bad joke. At the end of the story he is pictured having coffee with Maria, whining about being alone and wanting his good old reliable wife back, while simultaneously harbouring thoughts about the new secretary he has appointed, as she is groping inside her bag for the "single round-theworld ticket on the QE2" (p. 243). In effect, the narrative suggests, European forms of adultery are somehow superior (less deceitful, more romantic) to the white South African equivalent. The colonial cringe here is almost palpable.

\section{White women}

The white women characters in this story do not fare much better than the men, though Maria's predicament garners more sympathy than that of any other white woman in the story. This is at least partly because she is awarded more narrative space than any other. It is, however, also because it is her story with whom the intended readers of such novels will most powerfully identify, being as she is middle-aged, middle-class, English-speaking and, to add extra identification value, on the receiving end of marital infidelity. Though curiously, it is Jake who is the focaliser more often than not in sections dealing with Maria's life, so that the reader comes to know her from Jake's perspective more readily than from her own. Indeed, so completely is she depicted in relation to Jake only, that it comes as something of a surprise at the end of the story that she takes such bold initiative to leave, touching "like a secret caress" (p. 243) the cover of the travel brochure containing her "ticket out", though this desire may be read as a celebratory gesture towards women needing an escape from bourgeois/patriarchal entrapment. However, 
from the first page, Maria is portrayed as not much more than a vaguely disconcerting physical presence, which detracts from the feminist empowerment that Maria's decision to leave suggests. Jake, waking up in the middle of the night, finds her next to him:

Maria's ample form engulfs his space. Monopolises the cotton sheets. Her arm slops heavily over the edge of the bed and a thin line of saliva trickles from the corner of her mouth onto the crumpled cotton pillowcase. (p. 5.)

It could only be the combination of what might be considered a "typical male" such as Jake, with the helping hand of a very critical amanuensis, that could have spent quite as much verbal energy depicting the immensity of Maria's physicality. Jake's secretary is also all body: "Outwardly, she has a powerful womanly confidence. She knows the difference shoes with a heel make to the swing of her gait." (p. 41.) Zara, too, the female student Jake seduces, as Rosenthal (2004:5) has observed, seems "a little wooden" under the gaze that zooms in on "the smooth arch of her foot (...) [the] gentle curve of her shoulder (...) the outlined arc of a breast" and her "savage impenetrability" (p. 43). (The "savage" part of which manifests itself in her clawing and biting Jake!)

While such details certainly serve to reinforce Jake's crass objectification of women, they do not explain the overt physicality in the representation of the other female protagonist, Camille, in the parallel narrative, who is also the object of a "sexualising" gaze. Apart from being "an annoying [and unconvincing] foreign do-gooder" (Rosenthal, 2004:5), she is, like Pappi, Mátyás and Dr Belotti, a good white person, because she is a foreign white person, or so the narrative appears to demonstrate. She is defined in opposition to South African women and Afrikaans-speaking women in particular.

She does not look like the people who live here. Perhaps it is this that offends them. She does not perm her hair, nor set it in rollers, and her clothes are not always functional or sensible. She is definitely thinner than most of the women here too. (p. 116-117.)

Once again, the colonial cringe is apparent. From Camille's long neatly-coiffed to look un-coiffed hair down to her "strappy high heels" (p. 117). Even her name, which is reminiscent of a brand of French perfume (and including her romantic liaison with a handsome Italian doctor), she remains a card-board cut-out, a paper doll upon which are hung current fashions, both sartorial and behavioural, and ulti- 
mately she seems rather a flimsy but appropriately commodified representative of all that is best in the West.

Fred de Vries (2004a:28) is right to suggest that Camille is just one of many cliché-karakters (clichéd characters) in the book. Perhaps the responses of both De Vries and Rosenthal may be attributed to the discrepancy between the abundance of physical detail provided in fleshing out the characters, and the rather scant attention given to other aspects of characterisation. It is, however, the pretentious Juanita le Grange who epitomises the narrative treatment of a certain recognisable type of white woman to have emerged in post-apartheid South Africa. The type is the English-speaking product of a privileged and liberal background, who needs people to know that "she has a $\mathrm{PhD},(\ldots)$ that she is a communist, (...) that she married a man who died in 'the struggle'", and who is "quoted as saying, 'I hate capitalism but there's nothing wrong with capital,' in Style magazine" (p. 69). Disdain for the type is possibly shared by the reader, but the caricature cameo role the character is called upon to play is not adequate in demonstrating the ubiquity and resilience of this brand of white-privileged normativity. Indeed, Maria might conceivably be just such a type, but she gets away with it. So might many of the readers of the book, but the character's "gloved paw", "fat little body", and "peroxided very short hair" (p. 69) might allow them the false self-congratulatory comfort of not recognising themselves in her depiction.

\section{One rainbow, one nation, the younger generation}

It is the younger generation of South Africans depicted in the novel, however, having experienced something of post-apartheid racial integration, that is invested with the writer's attempt to move beyond stereotype and her hopes for a truly liberated new South Africa. Blom learns, as a result of her interaction with Zara, that she can be a "fairy" and a "friend" (p. 59) to the white child, and not, as the internalisation of racial shaming has convinced the young coloured girl, a "Hotnot" (p. 13), "[b]rown, like mud" (p. 25). However, it is when she is older, having returned from a relative in the Karoo (p. 124) and upon being invited to a party in Cape Town with Pieter and his university friends, that the narrative's celebration of integration is entertained. At the party, Pieter, for the first time, feels part of the social group, rather than an outsider (p. 177), and his acceptance hinges on his partner:

As the evening progresses, classmates he has never spoken to wander over to him and chat. At first he cannot understand it. 
Why all of a sudden? They've had all year to befriend him, why now. But after catching a few of their stolen glances at Blom, he starts to understand and a strange warm feeling creeps through him. (p. 182.)

The narrative does not reveal whether it is Blom's beauty or colour that engenders the sudden interest and the stolen glances. Yet, one cannot overlook the implication of tokenism, which in the predictably "white" version of integration, manifests itself as conciliatory assimilation, in which the group of white student engineers (with names like Piet and Jaco) clearly enjoy the novelty of a conservative boereseun ${ }^{10}$ dating a young coloured woman. But mere gesture aside, any real potential to pursue the possibility of a mixed race relationship is almost immediately undone by Mann in her authorial manipulation of a sub-plot, which reveals Blom's parentage and makes her Pieter's half-sister (p. 195). Clearly for the writer miscegenation is as difficult to negotiate as incest is.

\section{Conclusion}

Ultimately, it is left to the young Zara, sensitive artist with cosmopolitan sensibilities, to voice Mann's critique of whiteness. For the exhibition of student work that Jake is holding, Zara paints her first self-portrait. Entitled "Innocence", the portrait depicts Zara with "her eyes closed" and "[b]lack blood drip[ping] from her mouth" (p. 199). When Jake suggests that the portrait signifies the "satanic" rather than "innocence," her response is

Innocence is black, not white (...). White is a negation. It is not a colour, only a reflection. It does not exist. Within black, there is every colour. What you call innocence is simply a state of unknowing. Naivety. What I call innocence embraces all of life's colours, and celebrates it. (p. 199.)

Relevant and challenging as this definition of whiteness may be in switching the terms of the moral binaries governing the signification of good and evil, it does seem to be oddly misplaced. The black blood dripping from the subject's mouth much more readily signifies the character's psychic pain - the narrative reveals that she witnesses the murder of her mother - which leaves little room for "innocence" or a celebration of it. If this is the novel's philosophical cri- 
tique of whiteness, it seems ineffectual, competing, as it does, with other more likely interpretations of the portrait.

In One tongue singing the assumptions of universal white normativity emerge in the interstices of liberal discourse. Though the writer confronts and challenges official narratives of racial inequality, her work emerges as a product of an insular middle-class frame of reference that privileges a worldly (read Western) cosmopolitan largesse. This is done by elevating the gentility of European whiteness as exemplary, in comparison to the more plebeian and dubious parochialism of South African whiteness. In addition, the text seems reliant mostly on stereotypes to carry testimonies of apartheid atrocities. More disturbingly, it does so without any negotiation of the ways in which those stereotypes advance apartheid thinking beyond the topical backdrop it is intended to provide for plot-driven narratives, and into the lives and psyches of the readers. Representations of black men and women are marked by white Western preconceptions of black realities. The caricature of the weak, drunken coloured man, who is always caught with his pants down, is suffused with the suspicion emanating from colonial tropes of the dark, lascivious other. Such portrayals have been wholly discredited, and it is no wonder that the only place still left for them to thrive and multiply in is the pulp of pulp fiction. I hope to have demonstrated that the representations in this text, no matter how well-intentioned, nor how well received both locally and globally, sustain the sanctity and sovereignty of the European self. Indeed, the decorum and civility of European whiteness is off-set by the parochialism of South African whiteness and the novel tends to reify Western civilisation, even as it purports to celebrate the new multicultural possibilities invested in a post-apartheid younger generation of South Africans. The problem with such investments is that vindication precedes any effective (re)negotiation of complicity and culpability - which in turn relieves white South Africans of having their racial identity examined, made slippery, or uncomfortable.

\section{List of references}

BABB, V. 1998. Whiteness visible: the meaning of whiteness in American literature and culture. New York: New York University Press.

BHABHA, H.K. 1998. The white stuff. Art forum: 21-24, May.

BRINK, A. 2004. Superb novel about life's unpredictability. Sunday independent: 18, 8 Feb.

DE VRIES, F. 2004a. Mann roer clichés flink om roman te skryf. Rapport: 28, 25 Apr.

DE VRIES, F. 2004b. Singular white females. This day: 9, 30 May. 
FRANKENBERG, R. 1993. The social construction of whiteness: white women, race matters. Minneapolis: University of Minnesota Press.

IGNATIEV, N. 2005. Whiteness and class struggle. Historical materialism, $11(4): 227-235$.

KIRBY, R. 2005. Darrel Bristow-Bovey emeritus. Mail and guardian: 23, 4-10 Feb.

LEVINAS, E. 1969. Totality and infinity: an essay on exteriority. Pittsburgh: Duquesne University Press.

MANN, S. 2005. One tongue singing. London: Vintage.

NAJMI, S. \& RAJINI, S., eds. 2002. Introduction: white women inracialized spaces: imaginative transformation and ethical action in literature. Albany: State University of New York.

ROSENTHAL, J. 2004. Art and love. Mail and guardian: 5, 20-24 Feb.

SESHADRI-CROOKS, K. 2000. Desiring whiteness: a Lacanian analysis of race. London: Routledge.

SHOME, R. 1999. Whiteness and the politics of location. (In Nakayama, T.K. \& Martin, J.N., eds. Whiteness: the communication of social identity. Thousand Oaks: Sage. p. 108-122.)

STEYN, M. 2001. "Whiteness just isn't what it used to be": white identity in a changing South Africa. Albany: State University of New York Press.

SWERDLOW, A. 2003. Interview with Pamela Jooste. (Transcript of The Bookshelf: 1 Jun.) www.safm.co.za/transcripts Date of access: 2 Feb. 2004.

WEST, M. 2009. White women writing white: identity and representation in (post-)apartheid literatures of South Africa. Cape Town: David Philip.

WICOMB, Z. 2001. Five Afrikaner texts and the rehabilitation of whiteness. (In Kriger, R. \& Zegeye, A., eds. Culture in the New South Africa: after apartheid. Vol. 2. Cape Town: Kwela. p. 169.)

YOUNG, R.J.C. 2004. White mythologies: writing history and the West. 2nd ed. London: Routledge.

\section{Key concepts:}

Mann, Susan

One tongue singing

post-apartheid fiction

post-colonial whiteness studies

\section{Kernbegrippe:}

Mann, Susan

One tongue singing

postapartheid fiksie

postkoloniale witheidstudie 
